\title{
WARUNKI DO ROZWOJU KAPITAŁU LUDZKIEGO NA REGIONALNYCH RYNKACH PRACY W POLSCE
}

Celem opracowania jest analiza regionalnych rynków pracy w Polsce z punktu widzenia ich zdolności do tworzenia warunków do rozwoju kapitału ludzkiego, innymi słowy, warunków do przyciagania wykwalifikowanych zasobów tego kapitału. Wskazano na trzy zasadnicze cechy rynków pracy, które determinują efektywne wykorzystanie i rozwój tego kapitału: zdolność do tworzenia miejsc pracy dla wykwalifikowanych pracowników, oferowany poziom wynagrodzenia oraz rozmiary i charakter bezrobocia. Postawiono hipotezę, że obszary o lepszych warunkach na rynku pracy dla rozwoju zasobów ludzkich cechuje z reguły wyższy poziom kapitału ludzkiego. Są to jednocześnie obszary, które wykazują tendencję do przyciagania wyspecjalizowanych zasobów pracy. Wnioskowanie przeprowadzono na podstawie analizy danych opisujących rynki pracy w latach 1999-2011.

Analizy pozwoliły wskazać województwa, które borykają się z największymi problemami w tym zakresie. Są to przede wszystkim województwa wschodnie (podkarpackie, podlaskie, lubelskie oraz świętokrzyskie) oraz północne i północno-zachodnie (warmińskomazurskie, lubuskie, kujawsko-pomorskie, zachodniopomorskie). Zgodnie z tezami nowej geografii ekonomicznej relatywnie najszybciej do wymagań współczesnej gospodarki dostosowują się województwa, które mają dynamicznie rozwijające się metropolie. Jednocześnie regiony te wykazują tendencję do przyciaggania wyspecjalizowanych zasobów pracy oraz cechują się z reguły wyższym poziomem kapitału ludzkiego - tam siły koncentracji (dośrodkowe) przeważają na siłami odśrodkowymi.

Procesy zaobserwowane na regionalnych rynkach pracy uzasadniają potrzebę działań w kierunku tworzenia jak najlepszych warunków dla rozwoju kapitału ludzkiego (chodzi zwłaszcza o to, by nie popaść w pułapkę tanich miejsc pracy) oraz wskazują, że pożądane byłoby uruchomienie instrumentów przeciwdziałającym procesom regionalnej dywergencji.

Słowa kluczowe: kapitał ludzki, rynek pracy, zróżnicowania regionalne.

\section{WPROWADZENIE}

W warunkach rozprzestrzeniania się zasad funkcjonowania liberalnego rynku na całą gospodarkę światową oraz coraz swobodniejszego przepływu mobilnych czynników produkcji - jak wskazują dane statystyczne - przepływają one (w ujęciu terytorialnym) w kierunku biegunów wzrostu, o wykształconych, trwałych - bo opartych na jakościowych walorach - przewagach konkurencyjnych. Ich fundamentem - w najbardziej ogólnym ujęciu - są pozytywne sprzężenia między nowoczesnością gospodarki a jakością życia, które według Richarda Floridy zapewnia triada (tzw. 3T): technologia - talent - tolerancja $^{2}$.

\footnotetext{
${ }^{1}$ Dr Małgorzata Wosiek, Katedra Teorii Ekonomii i Stosunków Międzynarodowych, Wydział Ekonomii, Uniwersytet Rzeszowski, ul. Ćwiklińskiej 2, 35-601 Rzeszów, tel. 1787217 17, e-mail: mwosiek@univ.rzeszow.pl.

${ }^{2}$ R. Florida, Cities and the Creative Class, Routledge, New York-London 2005, s. 6.
} 
Równolegle osiągnięcia m.in. nowej geografii ekonomicznej wskazują, że wysoko wyspecjalizowane czynniki wytwórcze wykazują silną tendencję do przestrzennej koncentracji. Właściciele mobilnych czynników produkcji podejmują decyzję o lokalizacji na podstawie oceny oddziaływania sił dośrodkowych (sprzyjających koncentracji, determinowanych m.in. przez możliwości obniżania szeroko rozumianych kosztów produkcji lub osiagania wyższej stopy zwrotu przy niższym poziomie ryzyka) i odśrodkowych (sprzyjających decentralizacji, drenażowi, związanych ogólnie z koniecznością ponoszenia dodatkowych nakładów). W tym kontekście istotną determinantą mobilności zasobów pracy, a zwłaszcza wykwalifikowanego kapitału ludzkiego, są warunki oferowane przez lokalne oraz regionalne rynki pracy.

Wzajemne wzmacnianie się procesów liberalizacji oraz polaryzacji (koncentracji) z jednej strony premiuje obszary wysoko rozwinięte, umożliwiając im przyspieszenie stopy wzrostu gospodarczego, z drugiej pogłębia marginalizację obszarów problemowych. $\mathrm{Na}$ gruncie teorii kapitału ludzkiego związane jest to m.in. z generowaniem na obszarach problemowych kosztowych efektów akumulacji tego kapitału (jako skutek przeważajacych procesów wymywania), dla biegunów wzrostu zaś z możliwościami pozyskania wykwalifikowanych czynników wytwórczych bez konieczności ponoszenia nakładów na ich rozwój. Problemy te znacząco utrudniają i spowalniają dążenia do osiagnnięcia - postulowanej w polityce gospodarczej państw Unii Europejskiej - spójności społecznoekonomicznej. Kwestie te ze szczególną mocą dotyczą polskiej gospodarki, którą z jednej strony dzieli dystans od wysoko rozwiniętych krajów, a z drugiej boryka się ona z wewnętrznymi dysproporcjami rozwojowymi.

Na tym tle celem opracowania jest analiza regionalnych rynków pracy w Polsce z punktu widzenia ich zdolności do tworzenia warunków do rozwoju kapitału ludzkiego, innymi słowy - warunków do przyciagania wykwalifikowanych zasobów tego kapitału. Wskazano na trzy zasadnicze cechy rynków pracy, które determinują efektywne wykorzystanie i rozwój tego kapitału: zdolność do tworzenia miejsc pracy dla wykwalifikowanych pracowników (której przejawem jest sektorowa struktura zatrudnienia oraz kierunki i tempo jej zmian), oferowany poziom wynagrodzenia oraz rozmiary i charakter bezrobocia. Postawiono hipoteze, że obszary o lepszych warunkach na rynku pracy dla rozwoju zasobów ludzkich cechuje z reguły wyższy poziom kapitału ludzkiego. Są to jednocześnie obszary, które wykazują tendencję do przyciagania wyspecjalizowanych zasobów pracy. Wnioskowanie przeprowadzono na podstawie analizy danych opisujących rynki pracy w latach 1999-2011.

\section{SEKTOROWA STRUKTURA ZATRUDNIENIA}

W ogólnym ujęciu sektorowym zdolność regionalnych gospodarek do tworzenia miejsc pracy dla wykwalifikowanych pracowników związana jest z rozwojem sektora usług. Współcześnie stają się one nie tylko największym źródłem przyrostu miejsc pracy w ogóle, ale także takich, które wymagają wyższych kwalifikacji i wykształcenia. Z Narodowego Spisu Powszechnego wynika, że w Polsce w 2002 r. co czwarty pracownik w usługach miał wyższe wykształcenie, a tylko $6 \%$ osób miało wykształcenie podstawowe. $\mathrm{Z}$ kolei w rolnictwie $40 \%$ zatrudnionych legitymowało się wykształceniem podstawowym, a zaledwie $2,2 \%$ wykształceniem wyższym. Sektor przemysłowy w tym czasie 
angażował $10 \%$ zatrudnionych $\mathrm{z}$ wykształceniem wyższym, 36,7\% z wykształceniem średnim, a 42,8\% z zasadniczym zawodowym. ${ }^{3}$

Rozkład odsetka zatrudnionych w sektorze usług oraz wartości syntetycznego miernika odległości struktur pracujących (rys. 1) wskazuje na wyraźny geograficzny podział Polski w przekroju wschód-zachód (na niekorzyść wschodnich regionów). Liderem w skali kraju jest województwo mazowieckie (jest to zapewne wynik lokalizacji Warszawy), gdzie największy odsetek siły roboczej (w $2011 \mathrm{r}$. ponad 66\%) znajduje zatrudnienie w usługach, a struktury pracujących są najbardziej podobne do tych obserwowanych w krajach UE-15. Wyższymi wskaźnikami zatrudnienia w usługach (w porównaniu ze średnią krajowa) wykazują się ponadto województwa zachodnie i północno-zachodnie. Najmniej korzystnie w tym zakresie wypadają wschodnie województwa (podkarpackie, podlaskie, lubelskie, świętokrzyskie), gdzie ciągle znaczący jest udział zatrudnionych w rolnictwie (w 2011 roku około 32\% wobec 17,1\% w Polsce oraz 2,9\% w UE-15), a odsetek zatrudnionych $\mathrm{w}$ usługach jest relatywnie najniższy (ok. 45,5\% wobec 55,5\% w kraju i 73,2\% w krajach UE-15).

Warto zaznaczyć pozytywne zmiany dokonujące się w Polsce w latach 1999-2011 w strukturze zatrudnienia: we wszystkich województwach wzrastał udział pracujących w usługach, spadało zatrudnienie w rolnictwie, przy niewielkich zmianach zatrudnienia w przemyśle. Procesy te wiązały się ze zmniejszaniem dystansu wobec krajów UE-15 (o czym świadczą m.in. zmniejszające się wartości miary odległości struktur), ale nie wpłynęły znacząco na zmianę terytorialnego podziału Polski w tym zakresie.

Rys. 1. Odsetek zatrudnionych $w$ usługach, miara odległości struktury zatrudnienia ${ }^{4}$ (w porównaniu z krajami UE-15)

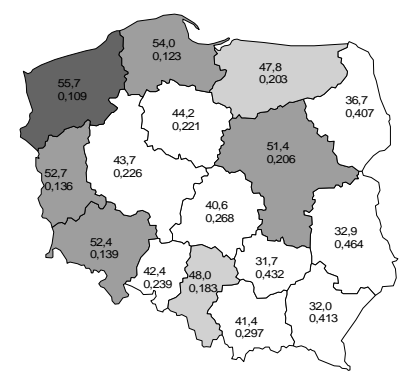

1999

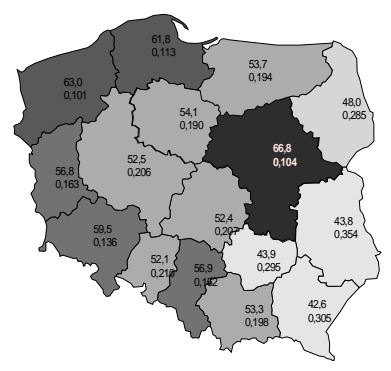

2011

Źródło: opracowanie na podstawie Banku Danych Lokalnych, www.stat.gov.pl (dostęp: 5.05.2013).

\footnotetext{
3 Rynek pracy w Polsce. Aspekty ekonomiczno-społeczne, red. Z. Dach, Wydawnictwo Uniwersytetu Ekonomicznego w Krakowie, Kraków 2008, s. 24-25.

${ }^{4}$ Syntetyczny miernik odległości struktur zatrudnionych obliczono według formuły:

$$
s_{t}=\frac{\sum_{i=1}^{k}\left|\alpha_{i t}-\beta_{i t}\right|}{2}, \quad(\mathrm{t}=0, \ldots, \mathrm{n})
$$

gdzie: $\alpha_{\mathrm{it}}$ - udział $i$-tej składowej w okresie $t$ struktury obiektu A (polskich regionów), $\beta_{\mathrm{it}}$ - udział $i$-tej składowej w okresie $t$ struktury obiektu B (kraje UE-15). Wartości miary mieszczą się w przedziale $<0,1>$. Im mniejszą wartość przyjmuje wskaźnik, tym bardziej struktura pracujących w województwie w roku $t$ zbliżona była do struktury pracujących w krajach UE-15 (K. Kukuła, Statystyczne metody analizy struktur ekonomicznych, Wydawnictwo Edukacyjne, Kraków 1996, s. 37, 79).
} 
Z punktu widzenia oceny różnic w skali wykorzystania kapitału ludzkiego w poszczególnych rodzajach działalności istotna jest nie tylko ocena proporcji zatrudnienia między głównymi sektorami gospodarki, ale także ich wewnętrzna kompozycja. Ważną rolę odgrywa obecność podmiotów gospodarczych w wysoko technologicznych sekcjach przemysłu oraz usług (KIS, knowledge-intensives services), w których występują relatywnie duże nakłady na technologię i kapitał ludzki, a ponad 1/3 pracowników (zwłaszcza w usługach) ma wyższe wykształcenie. ${ }^{5}$

Rys. 2. Regionalne zróżnicowanie zatrudnienia w wysoko technologicznych sekcjach przemysłu oraz usług
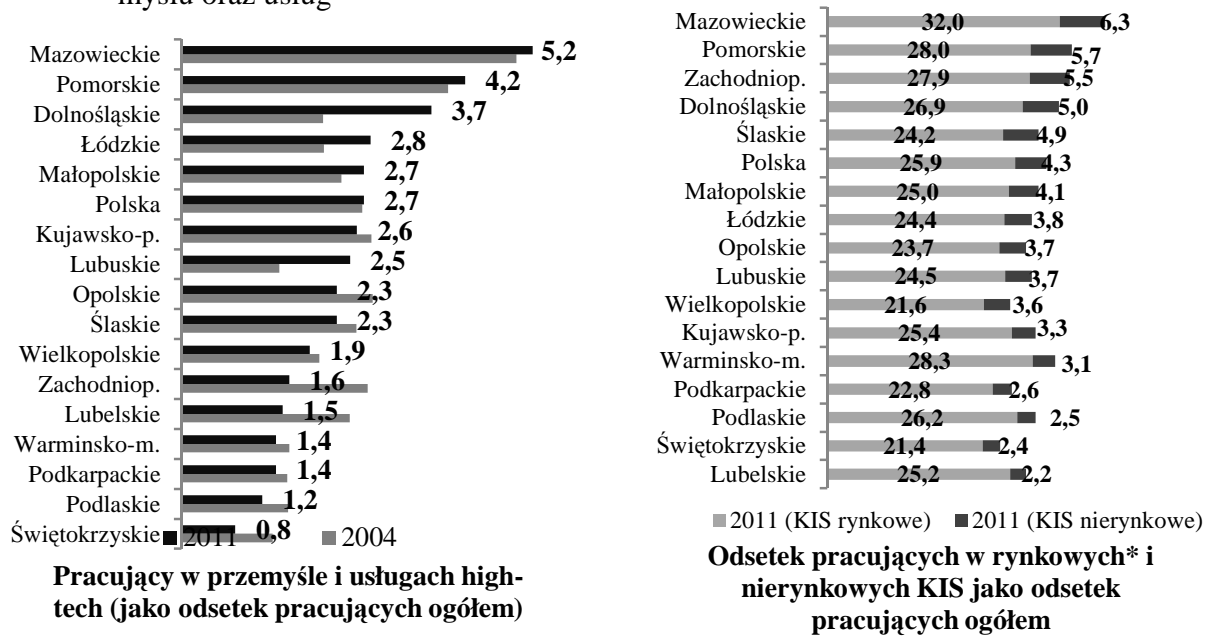

* z wyłączeniem pośrednictwa finansowego i usług zaawansowanych technologii.

Dla 2011 r. wg NACE Rev. 2, dla 2004 r. wg NACE Rev. 1.1.

Źródło: Eurostat, Employment in technology and knowledge-intensive sectors by NUTS 2 regions, http://epp.eurostat.ec.europa.eu/portal/page/ portal/statistics/search_database (dostęp: 18.05.2013).

Zgromadzone dane statystyczne (rys. 2) ujawniają wyraźną dominację województwa mazowieckiego w skali kraju. W tym województwie w 2011 r. udział pracujących w sektorach zaliczanych według klasyfikacji NACE (Rev. 2 - PKD 2007) do wysoko technologicznych (high-tech) był najwyższy i równocześnie prawie dwukrotnie wyższy niż średnia krajowa $(2,7 \%)$. Wskaźniki przekraczające poziom średniej krajowej osiagały ponadto cztery województwa: pomorskie, dolnośląskie, małopolskie oraz łódzkie. Najniższe wskaźniki w skali kraju cechowały najsłabiej rozwinięte województwa (świętokrzyskie, podlaskie, podkarpackie warmińsko-mazurskie oraz lubelskie). Co więcej, w tych regionach w latach 2004-2011 zmniejszał się odsetek pracujących w branżach zaawansowanych technologicznie. Zjawisko to było obserwowane także w pozostałych regionach (poza lubuskim), w których wskaźniki zatrudnienia w branżach high-tech były w $2011 \mathrm{r}$.

\footnotetext{
${ }^{5} \mathrm{~W}$ sektorze usług są to: usługi publiczne (edukacja, administracja publiczna, ochrona zdrowia) oraz usługi biznesowe zarządzania wiedzą i informacją w różnych jej postaciach. M. Cyrek, Rozwój sektora ustug a gospodarka oparta na wiedzy, Wydawnictwo Uniwersytetu Rzeszowskiego,, Rzeszów 2012, s. 82.
} 
niższe niż średnia krajowa. Działo się tak mimo że - jak wskazują inne badania ${ }^{6}$ - w latach 2000-2010 we wszystkich województwach w Polsce wzrosła liczba przedsiębiorstw zaliczanych do sektora high-tech. Niemniej jednak cytowane badania wskazują także, że w regionach o najmniejszym nasyceniu jednostkami high-tech procesy te dokonywały się mniej dynamicznie (świadczą o tym pogarszające się wskaźniki udziału w ogólnej liczbie takich przedsiębiorstw w kraju oraz powiększenie dysproporcji w zakresie liczby tych przedsiębiorstw w przeliczeniu na mieszkańca).

Przeprowadzone analizy prowadzą do wniosku, że choć w latach 1999-2011 wzrastała zdolność wszystkich polskich województw do generowania miejsc pracy dla wykwalifikowanych pracowników (o czym świadczy także m.in. rosnący w latach 2004-2011 we wszystkich województwach odsetek zatrudnionych w KIS), to jednak terytorialny rozkład możliwości i potencjału poszczególnych regionów w tym zakresie cechuje się znaczną inercją. Potencjał ten jest bowiem warunkowany przede wszystkim strukturalnie, a takie zmiany dokonują się powoli, w perspektywie długiego okresu. Wyraźnie rysuje się w tym względzie niekorzystna sytuacja województw położonych we wschodniej części kraju. W tych województwach dodatkowo wysoki udział zatrudnionych w nierynkowych usługach społecznych zawyża znaczenie sektora usług wiedzochłonnych (zob. rys. 2).

Choć we wszystkich województwach zaznacza się konwergencja w zakresie trójsektorowej struktury zatrudnienia względem krajów UE-15, to jednak zmiany te - w województwach o największych problemach strukturalnych - w mniejszym stopniu prowadziły do przepływu czynników wytwórczych do bardziej wydajnych i wiedzochłonnych zastosowań. Na poziomie regionalnym w Polsce procesom konwergencji w ogólnym układzie sektorowym towarzyszą bowiem procesy dywergencyjne wewnątrz poszczególnych sektorów. Poszczególne regiony modernizują swe gospodarki według odmiennych ścieżek rozwoju.

Na podstawie otrzymanych wyników można także stwierdzić, że w województwach o największym problemach strukturalnych, a jednocześnie o niskim poziomie produktu krajowego brutto (PKB) na mieszkańca (generalnie są to województwa wschodnie) silniej rozwijały się dziedziny zgłaszające zapotrzebowania na niewykwalifikowane (i przy okazji mało płatne) zawody, co z punktu widzenia konkurencyjności może być traktowane nawet jako zagrożenie dla gospodarki ${ }^{7}$. Regiony te $\mathrm{w}$ mniejszym stopniu włączają się w procesy modernizacyjne, a jednocześnie oferują relatywnie gorsze warunki dla rozwoju kapitału ludzkiego, m.in. poprzez zawężone możliwości inwestowania w ten kapitał poprzez wykonywanie pracy zawodowej.

\section{REGIONALNE ZRÓŻNICOWANIE WYNAGRODZEŃ}

Zdolność do przyciągania i zatrzymania wykwalifikowanych kadr w regionie zależy nie tylko od stworzenia odpowiednich, ale także odpowiednio opłacanych miejsc pracy. Poziom indywidualnych wynagrodzeń na rynku pracy uzależniony jest od płci, wieku, stażu pracy, poziomu wykształcenia czy grupy zawodowej. W skali makroekonomicznej zróżnicowania istnieją między głównymi sektorami gospodarki, a także w układzie prze-

\footnotetext{
${ }^{6}$ E. Wojnicka, P. Klimczak, M. Wojnicka, J. Dąbrowski, Perspektywy rozwoju matych i średnich przedsiębiorstw wysokiej technologii w Polsce do 2020 roku, PARP, Warszawa 2006, s. 106, 109, 124; M. Wosiek, Kapitat intelektualny $w$ rozwoju regionów Polski Wschodniej, Wydawnictwo Uniwersytetu Rzeszowskiego, Rzeszów 2012, s. 91-92.

${ }^{7}$ G. Gorzelak, B. Jałowiecki, Konkurencyjność regionów, „Studia Regionalne i Lokalne” 2000/1, s. 8.
} 
strzennym - między województwami (tab. 1). Dane statyczne ujawniają, że najwyższy poziom przeciętnych wynagrodzeń osiągali pracujący w województwie mazowieckim, a następnie śląskim, dolnośląskim oraz pomorskim. Relatywnie niskie wynagrodzenia uzyskiwali pracujący w świętokrzyskim, lubuskim, kujawsko-pomorskim oraz podlaskim. Najniższe płace otrzymywali pracujący w warmińsko-mazurskim i w podkarpackim. W tych województwach w 2011 roku przeciętne wynagrodzenia były o około 13-17\% niższe niż średnia krajowa, a o około $30 \%$ względem województwa mazowieckiego. Zaobserwowane prawidłowości były charakterystyczne dla większości typów działalności gospodarczej w przemyśle, budownictwie, a wśród usług dla hotelarstwa (sekcja I), obsługi nieruchomości (sekcja L) oraz usług administrowania (sekcja N). Wyższe dysproporcje (w granicach 20-30\%) odnotowano w handlu (sekcja G), transporcie (sekcja H) oraz działalności finansowej (sekcja K).

Tabela 1. Regionalne zróżnicowanie przeciętnych wynagrodzeń w 2011 r.

\begin{tabular}{|l|r|r|r|r|r|r|r|r|}
\hline \multirow{2}{*}{ Województwo } & \multirow{2}{*}{ Ogółem } & \multicolumn{1}{c|}{$\begin{array}{c}\text { Sekcja } \\
\text { J }\end{array}$} & $\begin{array}{c}\text { Sekcja } \\
\text { K }\end{array}$ & $\begin{array}{c}\text { Sekcja } \\
\text { M }\end{array}$ & Ogółem & $\begin{array}{c}\text { Sekcja } \\
\text { J }\end{array}$ & $\begin{array}{c}\text { Sekcja } \\
\text { K }\end{array}$ & $\begin{array}{c}\text { Sekcja } \\
\text { M }\end{array}$ \\
\cline { 2 - 9 } & \multicolumn{7}{|c|}{} & \multicolumn{3}{c|}{ Polska $=100$} \\
\hline Polska & 3625,2 & 5852,8 & 5818,9 & 4209,1 & 100,0 & 100,0 & 100,0 & 100,0 \\
\hline Łódzkie & 3246,0 & 4492,3 & 4500,3 & 3106,6 & 89,5 & 76,8 & 77,3 & 73,8 \\
\hline Mazowieckie & 4504,7 & 6867,6 & 7203,9 & 5509,5 & 124,3 & 117,3 & 123,8 & 130,9 \\
\hline Małopolskie & 3333,0 & 5033,3 & 5057,2 & 3793,3 & 91,9 & 86,0 & 86,9 & 90,1 \\
\hline Śląskie & 3794,6 & 4199,3 & 4892,1 & 3740,1 & 104,7 & 71,7 & 84,1 & 88,9 \\
\hline Lubelskie & 3257,1 & 4683,8 & 4170,2 & 3049,5 & 89,8 & 80,0 & 71,7 & 72,5 \\
\hline Podkarpackie & 3023,2 & 5457,3 & 4066,9 & 2999,3 & 83,4 & 93,2 & 69,9 & 71,3 \\
\hline Podlaskie & 3178,2 & 3821,6 & 4312,5 & 2747,4 & 87,7 & 65,3 & 74,1 & 65,3 \\
\hline Świętokrzyskie & 3137,9 & 3339,9 & 4306,2 & 2781,5 & 86,6 & 57,1 & 74,0 & 66,1 \\
\hline Lubuskie & 3074,0 & 4216,5 & 3793,2 & 3253,7 & 84,8 & 72,0 & 65,2 & 77,3 \\
\hline Wielkopolskie & 3284,4 & 4141,3 & 4818,0 & 3577,3 & 90,6 & 70,8 & 82,8 & 85,0 \\
\hline Zachodniopomorskie & 3289,6 & 4699,2 & 4261,3 & 2999,3 & 90,7 & 80,3 & 73,2 & 71,3 \\
\hline Dolnośląskie & 3587,3 & 4938,4 & 5309,2 & 3475,6 & 99,0 & 84,4 & 91,2 & 82,6 \\
\hline Opolskie & 3249,6 & 3710,1 & 4027,6 & 2744,2 & 89,6 & 63,4 & 69,2 & 65,2 \\
\hline Kujawsko-pomorskie & 3062,3 & 4035,0 & 4217,4 & 3153,8 & 84,5 & 68,9 & 72,5 & 74,9 \\
\hline Pomorskie & 3567,5 & 5198,4 & 4931,2 & 3538,2 & 98,4 & 88,8 & 84,7 & 84,1 \\
\hline Warmińsko-mazurskie & 3019,4 & 3458,9 & 4058,1 & 2762,8 & 83,3 & 59,1 & 69,7 & 65,6 \\
\hline
\end{tabular}

Sekcja J - informacja i komunikacja, Sekcja K - działalność finansowa i ubezpieczeniowa, Sekcja M - działalność profesjonalna, naukowa i techniczna (wg PKD 2007).

Źródło: opracowanie własne na podstawie danych GUS, Bank Danych Lokalnych, www.stat.gov.pl (dostęp: 13.05.2012).

Należy podkreślić, że największe dysproporcje wynagrodzeń (przekraczające zróżnicowania w zakresie przeciętnych dochodów z pracy) zanotowano w wiedzochłonnych sekcjach usług rynkowych (wg PKD 2007 - sekcje J oraz M). Na przykład w usługach informacyjnych i komunikacyjnych przeciętny poziom wynagrodzeń w najniżej sklasyfikowanych województwach (świętokrzyskie, warmińsko-mazurskie, opolskie, podlaskie, kujawsko-pomorskie) był niższy o około $40 \%$ niż średnio w kraju, a ponad dwukrotnie niższy w porównaniu z województwem mazowieckim. Warto zauważyć, że wysoki poziom wynagrodzeń w sekcji J (przekraczający średnią krajową, drugie miejsce w kraju po mazowieckim) od 2008 roku osiagali pracujący na Podkarpaciu, choć wynagrodzenia w innych sekcjach usług w tym województwie należały do najniższych w kraju. Może to 
być związane z kształtującą się specjalizacją w sektorze informatycznym w tym regionie (przejawem tego są m.in. funkcjonujące klastry informatyczne w tym województwie) i ciągle jednak wąskim rynkiem po stronie podaży pracy. Może też być przejawem ,kominów płacowych" w tym sektorze.

Najmniejszą lukę w wysokości przeciętnych wynagrodzeń, w odniesieniu do średniej krajowej (wynagrodzenia niższe o około 4-5\%), zaobserwowano w usługach nierynkowych (edukacja, ochrona zdrowia i opieka społeczna), co wynika z ogólnego charakteru rozwiązań instytucjonalnych.

Biorąc pod uwagę przeciętny poziom wynagrodzeń uzyskiwany w sekcjach J, K, M, można wskazać województwa, które oferują relatywnie najmniej atrakcyjne warunki płacowe w specjalizacjach wymagających relatywnie wyższego poziomu kapitału ludzkiego. Są to warmińsko-mazurskie, świętokrzyskie, podlaskie, kujawsko-pomorskie oraz lubuskie. Nieznacznie korzystniejsze wynagrodzenia (ale jedne z niższych w kraju) zanotowano ponadto $w$ województwach podkarpackim oraz lubelskim. Niekorzystne relacje płacowe stymulują odpływ kapitału ludzkiego z tych regionów w kierunku ośrodków oferujących atrakcyjniejsze warunki pracy (mazowieckie czy kraje UE-15) - o czym świadczą dane statystyczne opisujące ruchy migracyjne ${ }^{8}$. Poziom płac związany jest z rzeczywistymi efektami pracy. Te zaś - mierzone wartością dodaną brutto przypadającą na pracownika we wskazanych województwach (zwłaszcza w lubelskim, podkarpackim, podlaskim oraz świętokrzyskim) - są relatywnie niższe niż w innych regionach kraju9 ${ }^{9}$ Postulowany wzrost wynagrodzeń uwarunkowany jest zatem działaniami modernizacyjnymi i zmianami strukturalnymi, które podnosiłyby wydajność pracy w każdym z sektorów.

\section{ROZMIAR I CHARAKTER BEZROBOCIA}

Rozmiar i charakter bezrobocia diagnozują skalę niewykorzystania potencjału ludzkiego oraz utrudnienia w przepływie siły roboczej między działami gospodarki. Pozostawanie bez pracy, zwłaszcza w dłuższym okresie, obniża dyspozycyjne dochody oraz wiąże się z deprecjacją kapitału ludzkiego i narastaniem negatywnych form kapitału społecznego. Skala ubytku kapitału ludzkiego nasila się, gdy bez pracy pozostają osoby z wyższym wykształceniem.

Do oceny charakteru bezrobocia w układzie regionalnym wykorzystano m.in.:

- $\quad$ wskaźnik płynności bezrobocia $=\left(\mathrm{N}_{\mathrm{t}}+\mathrm{O}_{\mathrm{t}}\right) / 2 \mathrm{U}_{\mathrm{t}-1} ;$ gdzie $\mathrm{N}_{\mathrm{t}}\left(\mathrm{O}_{\mathrm{t}}\right)$ - napływ do bezrobocia (odpływ z bezrobocia) w okresie t; $U_{t-1}$-liczba bezrobotnych na koniec poprzedniego okresu. Im wyższa wartość wskaźnika, tym wyższa rotacja osób bezrobotnych na rynku pracy. Oznacza to, że zasób ten szybciej dostosowuje się do zmian sytuacji gospodarczej, co jest symptomem poprawy jego elastyczności ${ }^{10}$;

- wskaźnik niedopasowania strukturalnego na rynku pracy: $\mathrm{MM}_{\mathrm{t}}=\sqrt{\mathrm{u}_{\mathrm{it}}^{2}+\mathrm{v}_{\mathrm{it}}^{2}}$, gdzie

$u_{i t}$ - stopa bezrobocia rejestrowanego, a $v_{i t}$-stopa wakatów w województwie $i$ w ro-

\footnotetext{
${ }^{8}$ W 2010 r. dodatnim saldem migracji międzywojewódzkich (na 1000 mieszkańców) wykazywały się: mazowieckie $(2,41)$, pomorskie $(1,21)$, małopolskie $(1,10)$, dolnośląskie $(0,54)$, wielkopolskie $(0,49)$. Bank Danych Lokalnych, www.stat.gov.pl (dostęp: 13.05.2012).

${ }^{9}$ Według danych GUS województwa te pod tym względem zajmowały miejsca 13.-16. w rankingu 16 województw. Bank Danych Lokalnych, www.stat.gov.pl (dostęp: 13.05.2012).

${ }^{10}$ L. Kucharski, Przeptywy sity roboczej $w$ Polsce $w$ latach dziewięćdziesiatych, Wydawnictwo Uniwersytetu Łódzkiego, Łódź 2002, s. 99.
} 
ku $t$. Wartości wskaźnika mieszczą się w przedziale od 0 do $+\infty$. Im wyższa wartość, tym wyższe są niedopasowania strukturalne na rynku pracy ${ }^{11}$.

Analiza stóp bezrobocia rejestrowanego w latach 1999-2010 wskazuje po pierwsze na silne zróżnicowania regionalnych rynków pracy, po drugie na inercję tego układu w analizowanym okresie. Województwa, które wykazywały się relatywnie najwyższą stopą bezrobocia u progu okresu transformacji, również obecnie należą do niechlubnej grupy liderów w tym zakresie. Przede wszystkim są to województwa w Polsce północnej i północno-zachodniej (warmińsko-mazurskie, zachodniopomorskie, kujawskopomorskie, lubuskie), które do dzisiaj borykają się ze skutkami likwidacji Państwowych Gospodarstw Rolnych w początkach lat dziewięćdziesiątych XX wieku. Do grupy tej należą także województwa podkarpackie oraz świętokrzyskie. Nieco niższą stopą bezrobocia (ale wyższą niż średnia krajowa) wykazywały się pozostałe dwa wschodnie województwa - lubelskie oraz podlaskie. Obraz wschodnich województw może być jednak zniekształcony przez relatywnie wysoki poziom bezrobocia ukrytego ze względu na wysoki odsetek pracujących w rolnictwie w tych regionach.

Tabela 2. Poziom i charakter bezrobocia w województwach w 1999 i 2010 r.

\begin{tabular}{|c|c|c|c|c|c|c|c|c|c|c|c|c|}
\hline \multirow[t]{3}{*}{$\begin{array}{c}\text { Jednostka } \\
\text { terytorialna }\end{array}$} & \multirow{2}{*}{\multicolumn{2}{|c|}{$\begin{array}{c}\text { Stopa bezrobo- } \\
\text { cia rejestrowa- } \\
\text { nego }\end{array}$}} & \multirow{2}{*}{\multicolumn{2}{|c|}{$\begin{array}{c}\begin{array}{c}\text { Udział osób z } \\
\text { wykształce- } \\
\text { niem wyższym } \\
\text { ogólnej liczbie } \\
\text { bezrobotnych } \\
(\%)\end{array} \\
2\end{array}$}} & \multirow{2}{*}{\multicolumn{2}{|c|}{$\begin{array}{c}\begin{array}{c}\text { Miara niedo- } \\
\text { pasowania } \\
\text { strukturalnego }\end{array} \\
\mathbf{3} \\
\end{array}$}} & \multirow{2}{*}{\multicolumn{2}{|c|}{$\begin{array}{c}\begin{array}{c}\text { Wskaźnik } \\
\text { płynności } \\
\text { zasobu bezro- } \\
\text { bocia }\end{array} \\
4 \\
\end{array}$}} & \multicolumn{4}{|c|}{$\begin{array}{c}\text { Ranking } 2010 \\
\text { (dla 1-3, im wyższa } \\
\text { wartośc, tym niższa } \\
\text { lokata) }\end{array}$} \\
\hline & & & & & & & & & 1 & 2 & 3 & 4 \\
\hline & 1999 & 2010 & 2000 & 2010 & 1999 & 2010 & 1999 & 2010 & \multicolumn{4}{|c|}{2010} \\
\hline Polska & 13,1 & 12,4 & 2,57 & 10,47 & 0,122 & $\mathbf{0 , 1 2 4}$ & 1,26 & $\begin{array}{l}1,59 \\
\end{array}$ & - & - & - & - \\
\hline Łódzkie & 14,3 & 12,2 & 2,79 & 9,83 & 0,133 & 0,122 & 1,20 & 1,73 & 5 & 8 & 5 & 6 \\
\hline Mazowieckie & 9,5 & 9,7 & 2,81 & 11,85 & 0,090 & 0,097 & 1,19 & 1,50 & 2 & 12 & 2 & 12 \\
\hline Małopolskie & 10,2 & 10,4 & 2,88 & 12,12 & 0,093 & 0,105 & 1,27 & 1,43 & 4 & 13 & 4 & 13 \\
\hline Śląskie & 10,4 & 10,0 & 2,74 & 11,47 & 0,092 & 0,103 & 1,50 & 1,96 & 3 & 10 & 3 & 1 \\
\hline Lubelskie & 12,9 & 13,1 & 3,80 & 13,95 & 0,122 & 0,131 & 1,11 & 1,53 & 7 & 16 & 7 & 9 \\
\hline Podkarpackie & 14,5 & 15,4 & 2,70 & 11,67 & 0,138 & 0,154 & 1,02 & 1,54 & 12 & 11 & 12 & 8 \\
\hline Podlaskie & 12,5 & 13,8 & 3,16 & 12,32 & 0,121 & 0,138 & 1,22 & 1,39 & 10 & 14 & 10 & 15 \\
\hline Świętokrzyskie & 15,1 & 15,2 & 3,45 & 13,28 & 0,142 & 0,152 & 1,15 & 1,93 & 11 & 15 & 11 & 3 \\
\hline Lubuskie & 17,5 & 15,5 & 1,88 & 8,29 & 0,162 & 0,156 & 1,58 & 1,23 & 13 & 4 & 13 & 16 \\
\hline Wielkopolskie & 10,5 & 9,2 & 2,08 & 10,46 & 0,099 & 0,093 & 1,37 & 1,42 & 1 & 9 & 1 & 14 \\
\hline $\begin{array}{l}\text { Zachodniopo- } \\
\text { morskie }\end{array}$ & 18,1 & 17,8 & 2,26 & 8,09 & 0,166 & 0,178 & 1,27 & 1,8 & 15 & 3 & 15 & 4 \\
\hline Dolnośląskie & 16,0 & 13,1 & 2,12 & 9,55 & 0,151 & 0,133 & 1,34 & 1,94 & 7 & 7 & 8 & 2 \\
\hline Opolskie & 13,2 & 13,6 & 2,51 & 8,99 & 0,123 & 0,138 & 1,50 & 1,50 & 9 & 6 & 9 & 11 \\
\hline $\begin{array}{l}\text { Kujawsko- } \\
\text { pomorskie }\end{array}$ & 16,9 & 17,0 & 1,79 & 6,99 & 0,158 & 0,170 & 1,19 & 1,52 & 14 & 1 & 14 & 10 \\
\hline Pomorskie & 13,8 & 12,3 & 2,38 & 8,79 & 0,131 & 0,124 & 1,43 & 1,75 & 6 & 5 & 6 & 5 \\
\hline $\begin{array}{l}\text { Warmińsko- } \\
\text { mazurskie }\end{array}$ & 22,4 & 20,0 & 1,83 & 7,35 & 0,216 & 0,200 & 1,10 & 1,68 & 16 & 2 & 16 & 7 \\
\hline
\end{tabular}

Źródło: opracowanie własne na podstawie: Bank Danych Lokalnych, www.stat.gov.pl (dostęp: 9.07.2011) oraz Bezrobocie rejestrowane w I-IV kwartale 2010, GUS, Warszawa 2011.

\footnotetext{
${ }^{11}$ A. Rogut, Czynniki determinujace presję ptacowq w gospodarce polskiej-ujęcie regionalne [w:] Konwergencja gospodarcza Polski, red. Z.B. Liberda, PTE, Warszawa 2009, s. 238.
} 
Północno-zachodnie województwa charakteryzują ponadto najmniej efektywne w kraju dopasowania między strukturą podaży pracy a strukturą popytu na pracę. Województwa wschodnie osiągały nieco niższe wskaźniki niedopasowań strukturalnych, ale jednak mniej korzystne niż średnia krajowa. Z kolei jednak województwa północno-zachodnie cechują się relatywnie dynamicznym zasobem bezrobocia, co oznacza, że zasób ten szybciej dostosowuje się do zmian sytuacji gospodarczej. W regionach wschodnich bezrobocie ma zaś znacznie bardziej stagnacyjny charakter - wskaźniki elastyczności (dopasowań do zmian sytuacji gospodarczej) zasobu bezrobocia osiągają tam najniższy poziom w kraju. Do grupy województw o mniej płynnym zasobie bezrobocia zaliczono także mazowieckie. Prawdopodobnie stało się tak ze względu na wewnętrzne zróżnicowania w tym regionie tworzone przez Warszawę o dynamicznych przepływach na rynku pracy i tereny poza stolica, o bardziej rolniczym charakterze i większej stagnacji na rynku pracy.

W skali całego kraju bezrobocie dotyka przede wszystkim pracowników o niskich kwalifikacjach. Zaledwie $8-14 \%$ bezrobotnych legitymowało się wyższym wykształceniem. Jednak można zauważyć, że w latach 2000-2010 sytuacja osób z wyższym wykształceniem systematycznie się pogarsza (w 2000 r. takie osoby stanowiły 2,6\% ogółu bezrobotnych, w 2010 r. - 10,5\%). Jest to niewątpliwie wynik procesów upowszechniania się edukacji, a także pogłębiającej się asymetrii kompetencji w stosunku do poziomu wykształcenia i niedopasowania kierunków kształcenia do rynków pracy. Na tym ogólnym tle można wskazać województwa, w których osoby z wyższym wykształceniem stanowiły relatywnie większy odsetek bezrobotnych niż średnia krajowa. Są to: lubelskie, podlaskie, świętokrzyskie, podkarpackie, a także śląskie, mazowieckie oraz małopolskie. W mazowieckim, małopolskim oraz lubelskim może być to związane z relatywnie wysokim odsetkiem ludności z wyższym wykształceniem (wg szacunków BAEL w 2012 r. było to odpowiednio 29\%, 22,5\% 21\% ludności w wieku 15-64 lat, przy średniej krajowej 21,5\%). Szczególnie niekorzystnie rysuje się w tym względzie sytuacja na podkarpackim rynku pracy, gdzie odsetek ludności z wyższym wykształceniem należał do najniższych w kraju (w 2012 r. - 18,8\%), a stanowili oni 11,7\% bezrobotnych (przy średniej krajowej $10,5 \%)$.

\section{ZRÓŻNICOWANIE REGIONALNYCH RYNKÓW PRACY}

Na podstawie przedstawionych danych podjęto próbę wyodrębnienia możliwie najbardziej jednorodnych skupisk województw pod względem podobieństwa w zakresie wewnętrznej struktury poszczególnych obserwacji składających się na ocenę regionalnych rynków pracy (ze względu na oferowane warunki do rozwoju kapitału ludzkiego). Grupowanie przeprowadzono dla $2010 \mathrm{r}^{12}$ przy wykorzystaniu metody Warda oraz metody kśrednich. Do uporządkowania województw według oferowanych warunków dla rozwoju kapitału ludzkiego wykorzystano taksonomiczną metodę porządkowania liniowego, w której syntetyczny miernik oparto na średniej arytmetycznej znormalizowanych cech. W obliczeniach wykorzystano zestaw potencjalnych zmiennych diagnostycznych opisujących zdolność do tworzenia miejsc pracy dla wykwalifikowanych pracowników $\left(\mathrm{X}_{1}-\mathrm{X}_{5}\right)$, oferowany poziom wynagrodzenia $\left(\mathrm{X}_{6}-\mathrm{X}_{8}\right)$ oraz rozmiary i charakter bezrobocia (zmienne $\left.\mathrm{X}_{10}-\mathrm{X}_{12}\right)$ :

\footnotetext{
${ }^{12}$ Ze względu na brak porównywalnych danych w okresie 1999-2010.
} 
$\mathrm{X}_{1}$ - odsetek zatrudnionych w usługach,

$\mathrm{X}_{2}$ - miara odległości struktur pracujących (względem krajów UE-15),

$\mathrm{X}_{3}$ - wskaźnik zatrudnienia w rynkowych KIS,

$\mathrm{X}_{4}$ - liczba usługowych przedsiębiorstw high-tech (na 1000 mieszkańców),

$\mathrm{X}_{5}$ - liczba przemysłowych przedsiębiorstw high-tech (na $1 \mathrm{mln}$ mieszkańców),

$\mathrm{X}_{6}-$ poziom przeciętnych wynagrodzeń ogółem,

$\mathrm{X}_{7}$ - poziom przeciętnych wynagrodzeń w sekcji J,

$\mathrm{X}_{8}-$ poziom przeciętnych wynagrodzeń w sekcji M,

$\mathrm{X}_{9}$ - stopa bezrobocia rejestrowanego,

$\mathrm{X}_{10}$ - udział osób z wykształceniem wyższym w ogólnej liczbie bezrobotnych,

$\mathrm{X}_{11}$ - miara niedopasowań strukturalnych,

$\mathrm{X}_{12}$ - wskaźnik płynności zasobu bezrobocia.

Zmienne poddano weryfikacji statystycznej przy założonym poziomie współczynnika zmienności $10 \%$ oraz krytycznej wartości współczynnika korelacji liniowej Pearsona 0,85. Ostatecznie w obliczeniach wykorzystano siedem zmiennych: $\mathrm{X}_{3}, \mathrm{X}_{5}, \mathrm{X}_{6}, \mathrm{X}_{7}, \mathrm{X}_{9}$, $\mathrm{X}_{10}, \mathrm{X}_{12}$. Zmienne o charakterze destymulant $\left(\mathrm{X}_{9}, \mathrm{X}_{10}\right)$ przekształcono w stymulanty według formuły różnicowej ${ }^{13}$. Wszystkie zmienne poddano procedurze normalizacji na podstawie przekształcenia ilorazowego, odwołującego się do wartości ekstremalnych. Przyjęta metoda normalizacji pozwala zachować zmiennym ich zróżnicowaną wariancję i tym samym nadaje im swoiste, a równocześnie naturalne wagi ${ }^{14}$. Rezultaty obliczeń przedstawiono na rysunku 3.

Rys. 3. Ranking oraz wyniki grupowania województw ze względu na charakterystykę rynku pracy w $2010 \mathrm{r}$.
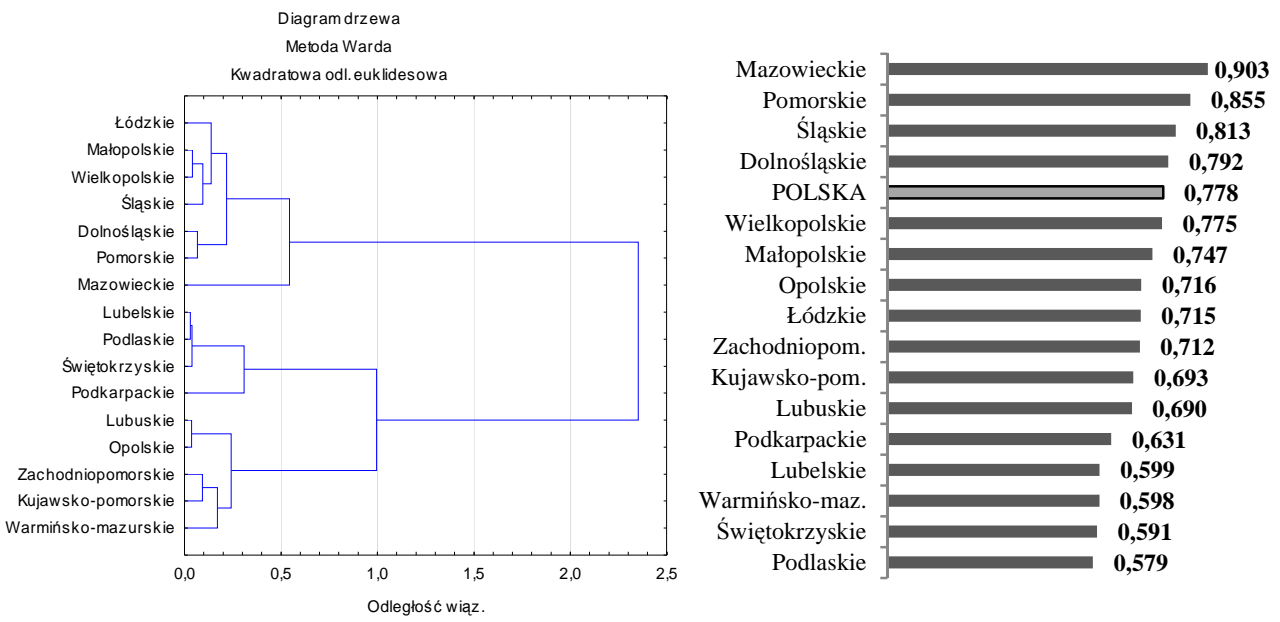

\footnotetext{
${ }^{13}$ Taksonomiczna analiza przestrzennego zróżnicowania poziomu życia $w$ Polsce $w$ ujęciu dynamicznym, red. A. Zeliaś, Wydawnictwo Akademii Ekonomicznej w Krakowie, Kraków 2000, s. 137.

${ }^{14}$ A. Młodak, Analiza taksonomiczna w statystyce regionalnej, Difin, Warszawa 2006, s. 42.
} 


\begin{tabular}{|c|l|c|l|l|l|}
\hline \multirow{2}{*}{ Gr. } & \multicolumn{1}{|c|}{ Województwo } & \multicolumn{3}{|c|}{ Średnia wartość dla skupienia } \\
\cline { 3 - 6 } & \multicolumn{1}{|c|}{$\begin{array}{c}\text { Syntetyczna } \\
\text { miara }\end{array}$} & $\begin{array}{l}\text { Struktura } \\
\text { sektorowa }\end{array}$ & \multicolumn{1}{c|}{ Płace } & \multicolumn{1}{c|}{ Bezrobocie } \\
\hline \multirow{2}{*}{1} & $\begin{array}{l}\text { Lubuskie, zachodniopomorskie, } \\
\text { opolskie, kujawsko-pomorskie, } \\
\text { warmińsko-mazurskie }\end{array}$ & 0,682 & $\begin{array}{l}\mathrm{X}_{3}=6,72 \\
\mathrm{X}_{5}=46,07\end{array}$ & $\begin{array}{l}\mathrm{X}_{6}=2999,7 \\
\mathrm{X}_{7}=3704,9\end{array}$ & $\begin{array}{l}\mathrm{X}_{9}=16,8 \\
\mathrm{X}_{10}=7,9 \\
\mathrm{X}_{12}=1,72\end{array}$ \\
\hline \multirow{2}{*}{2} & $\begin{array}{l}\text { Lódzkie, małopolskie, śląskie, } \\
\text { wielkopolskie, dolnośląskie, } \\
\text { pomorskie }\end{array}$ & 0,783 & $\begin{array}{l}\mathrm{X}_{3}=7,44 \\
\mathrm{X}_{5}=83,4\end{array}$ & $\begin{array}{l}\mathrm{X}_{6}=3281,1 \\
\mathrm{X}_{7}=4366,5\end{array}$ & $\begin{array}{l}\mathrm{X}_{9}=11,2 \\
\mathrm{X}_{10}=10,4 \\
\mathrm{X}_{12}=1,71\end{array}$ \\
\hline 3 & $\begin{array}{l}\text { Lubelskie, podkarpackie, } \\
\text { podlaskie, świętokrzyskie }\end{array}$ & 0,600 & $\begin{array}{l}\mathrm{X}_{3}=4,89 \\
\mathrm{X}_{5}=36,1\end{array}$ & $\begin{array}{l}\mathrm{X}_{6}=2992,1 \\
\mathrm{X}_{7}=4307,8\end{array}$ & $\begin{array}{l}\mathrm{X}_{9}=14,4 \\
\mathrm{X}_{10}=12,8 \\
\mathrm{X}_{12}=1,4\end{array}$ \\
\hline 4 & Mazowieckie & 0,903 & $\begin{array}{l}\mathrm{X}_{3}=9,70 \\
\mathrm{X}_{5}=111,3\end{array}$ & $\begin{array}{l}\mathrm{X}_{6}=4279,6 \\
\mathrm{X}_{7}=6382,3\end{array}$ & $\begin{array}{l}\mathrm{X}_{9}=9,7 \\
\mathrm{X}_{10}=11,9 \\
\mathrm{X}_{12}=1,39\end{array}$ \\
\hline
\end{tabular}

Źródło: opracowanie własne.

Wyniki obliczeń pozwalają wskazać województwo mazowieckie (a w zasadzie Warszawę) jako miejsce o najkorzystniejszych charakterystykach rynku pracy dla rozwoju kapitału ludzkiego. W czołówce rankingu (powyżej średniej krajowej) lokują się ponadto pomorskie, śląskie oraz dolnośląskie. Na najdalszych pozycjach zestawienia plasują się wschodnie województwa, w sąsiedztwie lubuskiego oraz kujawsko-pomorskiego.

Wyniki grupowania pozwalają wyróżnić cztery grupy województw o zbliżonych warunkach na rynku pracy dla rozwoju kapitału ludzkiego. Przeprowadzone procedury wyraźne podkreślają odrębność województwa mazowieckiego, które tworzy jednoelementowy zbiór (skupienie 4) o najwyższym syntetycznym wskaźniku oceniającym regionalne rynki pracy. Województwo to cechuje: najbardziej korzystna sektorowa struktura miejsc pracy (ze względu na warunki dla rozwoju kapitału ludzkiego), najwyższy poziom wynagrodzeń oraz najniższa stopa bezrobocia.

Kolejno w hierarchii plasują się województwa tworzące skupienie 2. Są to generalnie województwa z dużymi ośrodkami metropolitalnymi (Kraków, Wrocław, Poznań, Trójmiasto, Katowice). W województwach tych dokonują się korzystne zmiany strukturalne. Cechuje je ponadto relatywnie niska stopa bezrobocia oraz elastyczne dopasowania na rynku pracy.

Następna grupa 1 obejmuje generalnie województwa północne oraz północnozachodnie, które borykają się z problemem wysokiego bezrobocia, ale zasób ten relatywnie szybko dostosowuje się do zmian sytuacji gospodarczej. Na tych terenach relatywnie wolno przebiegają jednak procesy modernizacji i unowocześniania gospodarki.

Grupa 3, która obejmuje cztery wschodnie województwa, skupia regiony o najmniej korzystnych charakterystykach rynku pracy dla rozwoju kapitału ludzkiego. Niekorzystne charakterystyki zaobserwowano we wszystkich wymiarach rynku pracy, istotnych dla rozwoju zasobów tego kapitału. Na tych terenach zmiany strukturalne przebiegają z niezadowalającą dynamiką, poziom oferowanych wynagrodzeń należy do najniższych w kraju, a rynki pracy mają stagnacyjny charakter.

Zaobserwowane różnice są istotne statystycznie $(\mathrm{p}<0,05)$ dla wszystkich zmiennych (poza $\left.\mathrm{X}_{7}\right)^{15}$. U podstaw zaobserwowanych międzyregionalnych zróżnicowań legło przede

\footnotetext{
${ }^{15}$ Istotność różnic między skupienia przetestowano za pomocą nieparametrycznego testu Kruskalla-Wallisa (ze względu na niespełnione warunki konieczne do przeprowadzenia prostej analizy wariancji). Dla $\mathrm{X}_{7} \mathrm{p}=0,09$.
} 
wszystkim kształtowanie się zmiennych $\mathrm{X}_{5}, \mathrm{X}_{6}$, oraz $\mathrm{X}_{10}$. Najmniejszą rolę w podziale na grupy odegrały zmienne $X_{7}$ oraz $X_{12}$. Pogłębione badanie różnic między średnimi z poszczególnych grup według testu Scheffégo wykazało, że:

- dla zmiennej $X_{5}$ istotne statystycznie były różnice między grupami: 1-2, 1-4, 2-3 oraz 3-4,

- dla zmiennej $X_{6}$ istotne były różnice między mazowieckim i wszystkimi pozostałymi województwami,

- dla zmiennej $\mathrm{X}_{10}$ istotne były różnice między grupami: $1-2,1-3,1-4$ oraz 2-3.

Otrzymane wyniki sygnalizują, że różnice $\mathrm{w}$ zakresie charakterystyki regionalnych rynków pracy występują przede wszystkim między grupą województw wschodnich oraz północnych i północno-zachodnich (grupy 1 oraz 3 ) a pozostałymi województwami w kraju. Z kolei województwa zakwalifikowane do skupienia 2 cechują się znacznym podobieństwem do województwa mazowieckiego.

Oceniane charakterystyki regionalnych rynków pracy wykazują silny związek zarówno z poziomem kapitału ludzkiego (ustalonym na podstawie wyników uzyskanych w Diagnozie Społecznej 2011) ${ }^{16}$, jak i z atrakcyjnością osiedleńczą (mierzoną saldem migracji międzywojewódzkich na 1000 mieszkańców). Wartości współczynników korelacji przyjmują odpowiednio wartości z przedziału $[0,53 ; 0,76]$ oraz $[0,60 ; 0,86]$ i są istotne statystycznie. Jedynie regionalny rozkład odsetka osób z wykształceniem wyższym w ogólnej liczbie bezrobotnych $\left(\mathrm{X}_{10}\right)$ oraz wskaźnika płynności zasobu bezrobocia $\left(\mathrm{X}_{12}\right)$ nie wykazuje silnych związków z poziomem kapitału ludzkiego oraz saldem migracji (współczynniki korelacji Pearsona przyjmują bezwzględne wartości ok. 0,10). Otrzymane wyniki pozytywnie weryfikują postawiona hipotezę badawczą, że w układzie regionalnym w Polsce obszary o lepszych warunkach na rynku pracy dla rozwoju zasobów ludzkich cechuje z reguły wyższy poziom kapitału ludzkiego. Są to jednocześnie obszary, które wykazują tendencję do przyciagania wyspecjalizowanych zasobów pracy.

\section{PODSUMOWANIE}

Ze względu na rozprzestrzeniającą się liberalizację i wynikającą stąd rosnącą mobilność czynników wytwórczych, zwłaszcza pracy, zmiany na regionalnych rynkach pracy powinny zmierzać w kierunku zapewniania jak najlepszych warunków dla rozwoju i akumulacji wysoko wykwalifikowanych zasobów kapitału ludzkiego. Takie zmiany powinny zahamować procesy drenażu i powinny się przyczynić do poprawy ogólnego poziomu rozwoju społeczno-gospodarczego, a w konsekwencji dobrobytu mieszkańców.

Przeprowadzone analizy pozwoliły wskazać województwa, które borykają się z największymi problemami w tym zakresie. W szczególnie niekorzystnym położeniu znajduja się cztery wschodnie województwa: podkarpackie, podlaskie, lubelskie oraz świętokrzyskie. Problemy tych regionów są szczególnie trudne i złożone, gdyż niedociagnięcia ujawniają się równolegle $\mathrm{w}$ wielu charakterystykach regionalnych rynków pracy, nakładają się na siebie i wzajemnie się wzmacniają. W trudnej sytuacji znajdują się także województwa północne oraz północno-zachodnie, które na skutek procesów modernizacyjnych u progu transformacji (co wiązało się głównie z ograniczeniem zatrudnienia w sektorze

\footnotetext{
${ }^{16}$ D. Węziak-Białowolska, I.E. Kotowska, Pomiar kapitału ludzkiego i jego zróżnicowanie wedtug cech demograficznych, [w:] Rynek pracy i wykluczenie spoteczne w kontekśsie percepcji Polaków - Diagnoza Spoteczna 2011 , red. I.E. Kotowska, Warszawa 2012, s. 61.
} 
rolniczym) borykają się z wysoką skalą niewykorzystania potencjału ludzkiego. Relatywnie najszybciej do wymagań współczesnej gospodarki dostosowują się te województwa, które mają dynamicznie rozwijające się metropolie.

Procesy zaobserwowane na regionalnych rynkach pracy w Polsce uzasadniają działania w kierunku tworzenia jak najlepszych warunków dla rozwoju kapitału ludzkiego chodzi zwłaszcza o to, by regionalne gospodarki nie wpadły w pułapkę tanich miejsc pracy. Z kolei przedstawione międzywojewódzkie zróżnicowania wskazują na potrzebę uruchomienia odrębnych instrumentów stymulujących takie przemiany poszczególnych regionalnych rynków pracy oraz wskazują, że pożądane jest podjęcie działań zapobiegającym procesom regionalnej dywergencji. Jest to równocześnie przesłanka do częstszego podejmowania interwencji na tych rynkach z poziomu regionalnego, gdyż daje to możliwość dopasowania narzędzi do wewnętrznych problemów, uwarunkowań i potrzeb poszczególnych województw.

\section{LITERATURA}

[1] Bezrobocie rejestrowane w I-IV kwartale 2010, GUS, Warszawa 2011.

[2] Cyrek M., Rozwój sektora ustug a gospodarka oparta na wiedzy, Wydawnictwo Uniwersytetu Rzeszowskiego, Rzeszów 2012.

[3] Powszechny Spis Rolny, GUS, Warszawa 2003.

[4] Florida R., Cities and the Creative Class, Routledge, New York-London 2005.

[5] Gorzelak G., Jałowiecki B., Konkurencyjność regionów, „Studia Regionalne i Lokalne” 2000/1.

[6] Kucharski L., Przepływy sity roboczej w Polsce w latach dziewięćdziesiatych, Wydawnictwo Uniwersytetu Łódzkiego, Łódź 2002.

[7] Kukuła K., Statystyczne metody analizy struktur ekonomicznych, Wydawnictwo Edukacyjne, Kraków 1996.

[8] Młodak A., Analiza taksonomiczna w statystyce regionalnej, Difin, Warszawa 2006.

[9] Rogut A., Czynniki determinujace presje ptacowa $w$ gospodarce polskiej-ujęcie regionalne, [w:] Konwergencja gospodarcza Polski, red. Z.B. Liberda, PTE, Warszawa 2009.

[10] Rynek pracy w Polsce. Aspekty ekonomiczno-spoteczne, red. Z. Dach, Wydawnictwo Uniwersytetu Ekonomicznego w Krakowie, Kraków 2008.

[11] Taksonomiczna analiza przestrzennego zróżnicowania poziomu życia w Polsce w ujęciu dynamicznym, red. A. Zeliaś, Wydawnictwo Akademii Ekonomicznej w Krakowie, Kraków 2000.

[12] Węziak-Białowolska D., Kotowska I.E., Pomiar kapitału ludzkiego i jego zróżnicowanie wedtug cech demograficznych, [w:] Rynek pracy i wykluczenie społeczne w kontekście percepcji Polaków - Diagnoza Społeczna 2011, red. I.E. Kotowska, Warszawa 2012.

[13] Wojnicka E., Klimczak P., Wojnicka M., J. Dąbrowski, Perspektywy rozwoju małych i średnich przedsiębiorstw wysokiej technologii w Polsce do 2020 roku, PARP, Warszawa 2006.

[14] Wosiek M., Kapitat intelektualny w rozwoju regionów Polski Wschodniej, Wydawnictwo Uniwersytetu Rzeszowskiego, Rzeszów 2012.

\section{CONDITIONS FOR DEVELOPMENT OF HUMAN CAPITAL AT REGIONAL LABOUR MARKETS IN POLAND}

The aim of the study is to analyse regional labour markets in Poland concerning their abilities to create conditions for human capital development. The assessment was based on: ability to create workplaces for qualified employees, the offered level of remunerations as well as a scale and character of unemployment. There was formulated a hypothesis that are- 
as with such labour market conditions that are more favourable for development of human capital are characterised by higher level of human capital. These are simultaneously the areas that tend to attract professional labour resources.

The conducted analyses (covering period 1999-2011) allowed to indicate the voivodeships that struggle with the most serious problems within this sphere. These are, most of all, the east voivodeships (podkarpackie, podlaskie, lubelskie and świętokrzyskie) as well as the north and north-west voivodeships (warmińsko-mazurskie, lubuskie, kujawsko-pomorskie, zachodniopomorskie). In consistency with some thesis of a new economic geography, the voivodeships with developing metropolises are adopted to requirements of the modern economy with comparatively the highest dynamic. Simultaneously, these regions are characterized by tendency to gather qualified labour force and by usually higher level of human capital. In these regions concentration forces are prevailing decentralist ones.

The processes observed on regional labour markets justify a need for actions directed at creation of the best conditions for development of human capital - especially it comes to not to fall into a trap of cheap workplaces and indicate that it would be desired to use instruments counteracting processes of regional divergence.

Keywords: human capital, labour market, regional disparities

\section{DOI: 10.7862/rz.2013.mmr.63}

Tekst złożono w redakcji: wrzesień 2013

Przyjęto do druku: grudzień 2013 